\title{
密度を尺度とした市街地の変容過程に関する研究
}

\section{（その 1）人口集中地区の変動過程の分析注1)}

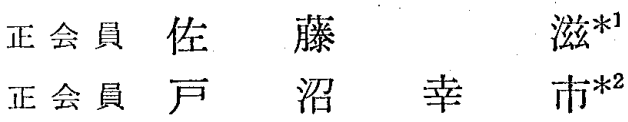

\section{1.はじめに}

市街地全体のマクロな成長・発展あるいは衰退の過程 は，あたかも原生動物が運動するがごとく，ある一定の リズムでいくつかの異なる変動パターンを繰り返すこと により進行する。そしてこのような市街地全体の変動は 市街地内部の物的構成の変容と密接に関連するものと考 えら扎る。

今日のマクロな市街地の問題は以下の三点に集約され よう。第一は東京，大阪にみる市街地の巨大化である。表 一 2 亿示すと㧍り 1960 年以来 15 年で倍增した 2 巨大 市街地の人口は，1975 年の時点で東京巨大市街地が約 2000 万人，大阪巨大市街地が約 1000 万人となり，こ の 2 巨大市街地に日本人の 3 人に 1 人は住んでいること になる。後述するようにこれらの巨大市街地は，元来独 立していた数多くの市街地を飲み込み非常な勢いで搪大 を続けている。そしてこのような市街地の巨大化は防災 的側面，居住環境の側面，交通・輸送の側面などで様々 な困難な問題を生じており，巨大市街地の拡大を制御で きないとすればこれらの問題はますます深刻なむのとな るであろう。

第二の問題点は, 市街地の高密化と密度配置棈造の混 乱といら密度に係わる問題である。ここで言ら市街地の 高密化とは二つの側面がある。一つは人口と併せて建築 物，自動車など物的な施設や装置を含めた総合的な物的 密度の高密度化であり，他の一つはマシション建設の集 中化などにより市街地の一部に生じる局所的な高密化で ある。後述するように市街地の人口密度は明治以来低密 化の一途をたどり現在もなおそれは進行中であるが，明 治以降に市街地の中に持ち込まれた種々の物的施設や装 置による負荷はマンーマシン系としての現代の市街地に おいて重要であり，これらによる市街地の高密化は大き な問題である:そしてこのような高密化が，市街地中心 部における極端な人口密度の低下と周辺部に㧍ける無秩 序なスプロール，局地的高密化といった密度配置構造の 混乱と重り合うことにより市街地における問題を一層複

*1 早稲田大学 助手.工修

*2 早稻田大学 教授.工博

(昭和 54.年 11 月 26 日本稿受理・討論期限昭和 56 年 7 月末日)
雑なものとしている。

第三の問題点は弱小市街地の衰退化である。高度経済 成長以降のモータリゼーションの長足の発展により, 元 来農村地带に括ける重要な生活拠点であった人口 5 千〜 1 万人程度の弱小市街地の衰退化が農村地帯における生 活便益を低下させ，大都市部との格差を一層桩大させ ている。

さて,これらの問題点は市街地の規模と密度の問題に 集約され，この 2 つ尺度で市街地の成長や衰退などの 変動を分析することにより，明確に問題を定位できるも のと考える。本研究「密度を尺度とした市街地の変容過 程に関する研究」全体は, このように市街地の変動過程 を密度と規模という 2 つの尺度でとらえその実態と変動 のメカニズムを明らかにするとともに，それが市街地の 土地利用, 密度分布, 道路ネットワークなどの物的構成 の変容とどのように関連しているかを明らかにすること を目的とする。

さて,このよらな目的老持つ本研究は計画論との関連 で概略二うの視点を有している。第一は地域計画, 国土 計画に倸わる視点である。国土全体，あるいは広域的な 地域の中に扝いて，個々の市街地のマクロな変動を立地 条件や社会経済的背景との関連で分析しその実態を明ら かにすることは，これらの広域的な計画にとって有意義 であると考える。第二は都市計画，市街地計画に係わる 視点である。市街地の変動過程を明らかにし，これと内 部の物的変容の関連を明確にすることは土地利用計画, 密度配置計画に関して意味ある知見を与えるものと考光 る。

さて以上のような全体的研究意図の中に括いて本編は まず，1960 年から 1975 年までの国勢調査におけ方人口 集中地区の資料を用いて，個々の市街地の変動を国土全 体の中に扔ける立地や社会経済的背景，さらに市街地の 規模などとの関連で分析し，その実態を明らかにするこ とを目的とする。

\section{2. 市街地及びその規模, 密度, 変動の定義}

2-1市街地の規定方法注2)

一般に市街地とは『人家の密集したにぎやかな土地』 （広辞苑より）のことでありその規定方法には以下の二 
つがある。

(1) 一定規模以上の人口が一定密度以上で集住してい る土地を市街地とする。

(2) 都市的土地利用が連担している土地を市街地とす る。

この二つの方法のうち(1) 厳密な定義が可能である が, 密度規定のための基礎単位が大きすぎると, 市街地 の周辺部で農地などを大量に市街地にかかえこんでしま らことになる。また(2)の方法は家屋の連担, 土地利用構 成, 農地面積比率などにより都市的土地利用を定義して 行ならが，地図上で簀略化して行なえば容易に市街地を 設定することができる。奉際には人口集中地区の基淮や 高山 (1949)，太田 (1964) などで提案された方法はこれ ら二つの方法を並用している。人口集中地区は『市区町 村の区域内で人口密度の高い調查区がたがいに隣接し て，その人口が 5000 人以上となる地域』をいい，人口 密度の規準を 4000 人 $/ \mathrm{km}^{2}$ 以上としている。そしてこ れに工場用地, 鉄道用地, 学校など都市的土地利用が一 定比率以上含まれる調查区が隣接している場合, これも 含むこととし，(1)の方法を主にし(2)の方法を補助的に用 いていることになる。このような人口集中地区の設定方 法は国勢調查の調査区を最小単位としているため, ミニ 開発のような高密度な住宅地化が一部で起こると, 農地 を多く含んだ調查区全体が人口集中地区に繰り込まれ， 実態的な市街地の境界と異なるなど久点もあるが，全国 ベースで市街地の分析を行なうためには唯一の資料であ り本論では全面的にこれを用いている。

さて国勢調查における人口集中地区以市区町村単位で 設定され，その境界を越えて連担していても別々の人口 集中地区としているが，本論に扔いては市区町村界を越 えて連担しているものは一つの市街地として扱ってい る。したがって東京を中心とする巨大連担市街地は一都 三県にまたがるひ亡で状の市街地を一つの市街地として 扱からことになる。

すなわち本論においては、行街地とは人口集中地区と 同一である。但し，市区町村界を越えて連担しているも のは全体で一つの市街地とみなす。と定義する。

2-2 市街地の変動の定義

さて 1960 年以降時点に掞ける人口集中地区のデータ を時亲列的に分析するためには以下のような困難がとも なら。

(1) 本論では, 行政界を越えて連担しているDID は 一つの市街地とみなすが，原資料では行政区界ごとに別 個の DID が設定されている。

(2) 1960 年から 1975 年の間に, はじめは別個な DID だったものが連担したり, 新たに DID が発生し,これ が隣接市町村の DID に連担する，あるいは一市町村の 中にあった複数の DID が連担して一つの DID になる
など特に大都市圈においては DID の発生・連担に関し 非常に複雑な変動があり原資料に大幅な手直しが必要と なった。

(3) 市区町村の合併や分割が期間内にある場合，(2)と 同様な手直しが必要となった。

このような複雑な DID の変動を整理するため本論で は次のような定義を行なら。

1) 連担市街地，連担 DID

2 以上の市区町村に設定されている個々の DID 区域 が，それらの市区町村の行政区間の境界を越え，互いに 隣接し 2 以上の市区町村にまたがる一体の DID を形成 している場合，この状態を「連担」と呼び，それらの一 体となった DID 全体を「連担市街地，連担 DID」と呼 s゙。

2). 市街地，DID の接合

同一市区町村内に打いて，T年に打汀る 2 以上の DID の区域のそれぞれの一部または全部の範囲が（T+ 5）年における 1 個の DID の区域に含まれる場合，こ の現象を「接合」と呼ぶ。これは実態的には「連担」と 同義である。

3）市街地，DID の分離

同一の市区町村内において，T年に抒ける 1 個の DID の区域の一部ずつが $(T+5)$ 年に拈ける 2 以上の DIDのそれぞれの区域に含まれる場合, この現象を 「分離」と呼ぶ。

4) 市街地, DID の発生

$T$ 年において DID が設定されていなかった地域に, $(T+5)$ 年に唟いて DID が設定された場合，この現象 を「発生」と呼ぶ。

5) 市街地, DID の消滅

$T$ 年における，あるDID，の区域に $(T+5)$ 年にお いて DID が設定されなかった場合,この現象を!消 減」之呼ぶ。

この他市区町村の合併により，以前市区町村界学越え て連担していた市街地が一つの DID として表章された rDID の一体化」や，逆に市区町村の分割により，一 つの DID であったものが二つ以上の DID として表章 される「DIDの分割」などが人口集中地区の整理にお いて問題となるが，もともと連担した. DID を一つの市 街地とみる本論に拈いては, 実態的な意味を持たない。

さてこのような市街地の動態をむとめたのが表一1 で ある。これによると 1960 年時点で 800 余りであった市 街地が 1975 年時点では 1000 を越えている。そして各 5 年閒にほぼ 200 前後の市街地が発生し，30 前後が消 滅（市街地たる人口規模を失なって）している。また 1965 年以降接合も増加し, 同一市区町村内に押泫市 街地に活発な動きがあったことがわかる。

2-3，市街地の規模と密度に係わる指標の定義 
市街地の変動を規模と密度といら二つの概念で説明し ようとするとき，その概念を明確に表現する指標を定義 しなければならない。本論では，市街地の規模は市街化 指数で, 密度は市街地人口密度で表現している。算定式 は以下の通りである。

・市街化 指 数=市街地人口×市街地面積

$$
=\text { DID 人口 } \times \text { DID 面積 }
$$

- 市街地人口密度＝市街地夜間人口/市街地面積

$$
=\mathrm{DID} \text { 人口 } / \mathrm{DID} \text { 面積 }
$$

な扮市街化指数については戸沼が昭和 35 年の DID を 取り上げてその市街地規模の理解の際に案出した概念で あり (吉阪・户沼 1965 参照)，案出の意図は市街地の規 模を判定寸る際，人口規模と面積規模ではランキングが ずれて一律に比較出来ないが，積值を用いるとこの矛 盾が解消されること，1万人の人口が $1 \mathrm{~km}^{2}$ の市街地 での地人相関の都市活動を示す 1 単位といらことになる が，こ礼は単位として理解しやすいこと，また市街化指 数は人口密度が一定に想定されると，以下のごとく人口 もしくは面積の自乗の式で表わすことができ，これは都 市活動が人口の単なる一次函数ではなく実感的には乗数 的なむのであるという点と一致することなどにより，密 度判定のある市街地の総合指標としてこれを採用したも のである。

$$
\begin{aligned}
\cdot \text { 市街化指数 }= & (\text { DID 人口密度 }) \times(\text { DID 面積 })^{2} \\
= & (\text { DID 人口密度の逆数 }) \\
& \times(\text { DID 人日 })^{2}
\end{aligned}
$$

さらに市街化指数, 市街地人口密度の年ごとの变化を 表現するために以上の 2 指標を定義する。

- 市街化指数变化率 $=\frac{(n+5) \text { 年度の市街化指数 }}{n \text { 年度の市街化指数 }}$

- 市街地人口密度変化率

$$
=\frac{(n+5) \text { 年度の市街地人口密度 }}{n \text { 年度の市街地人口密度 }}
$$

この 2 指標の組合せにより市街地の変動を表現するこ ととする。

$2-4$ 分析における時期区分

本論では資料的制約から 1960 年から 1975 年までの 15. 年間に限定して市街地変動の分析を行なっている。 この時代は戦後の復興をようやく終え, 高度経済成長が 軌道にのり, 近年の都市問題, 地域間格差など様々な人 間居住にかかわる問題が噴出した時代であり，この 15 年に限定してわが国における市街地変動の実熊を明らか にすることは十分意味あると考える。

さて国勢調查の人口集中地区に係わる資料は 1960 年 から 1975 年までの 5 年ごとの 4 時点で得ることができ るが, 動態的分析においてはこの 15 年を 5 年ごとの期 間に区分して分析を行なっている。ここではこれら期間 の市街地変動にかかかる時代的背景を分析の前提として 整理して扔く。
まず第1期は 1960 年から 1965 年で，国民所得倍増 計画，全国総合開発計画などにより高度経済成長政策が 選択され太平洋ベルト地域に集中的な産業資本の投下と 公共投資が行なわれた。これに続く 1965 年から 1970 年 の第 2 期は高度経済成長の爛熟期ともい党る時代で大都 市圈に扮ける地伍高滕, 公害問題, 無秩なスプロールな どの都市問題や国土レベルにおける過密過疎問題などが 深刻化し，反公害運動や新全総における大規模開発反対 運動などが一部で起きている。そして第 3 期の 1970 年 から 1975 年は 10 年以上続いた高度経済成長の矛盾が 一挙に噴出し，1973 年のオイルショックを契機として 経済政策，地域開発政策が大きな転換期を迎えることに なる。

このよらな時代的背景の中で個々の市街地がどのよう に変動したのか，それが国土の中での立地，市街地の規 模とどのようにかかかり合っていたのが以下の分析に より明らかにする。

\section{3. 市街地の規模よ人口密度の変遷}

\section{3-1 歴史的概観}

市街地規模と人口密度を都市の長い歴史にさかのぼっ て調べてみると，わが国に限らず世界的な傾向として， 市街地規模が搪大して人口密度が低下していることがわ かる。とくにエネルギー革命以後, 都甫に 機械力が導 入さ机て, 市街地の境界条件および市街地立地の条件が 緩和されて市街地規模の急速な拡大が㧍こり, 密度が低 下した。且つ, 市街地に非住宅施設が大量に持ちこまれ たことも，人口密度が低下した 主要因であった。江戸 時代の市街地人口密度は相当に高かったと想定され，例 えば江戸の町人町では方キ口 6〜7 万人と推定されてい るが，明治の初期の市街地では方キロ 2 3 万人，明治 期 2 万人, 大正期 1.5 万人, 昭和期 1 万人と推定されて いる注 3 )。

今日でも多数の市街地の出現, 一つの市街地規模の巨 大化など総じて市街地規模の桩大にともなら人口密度の 低下涜き, 昭和 35 年加同 50 年の DID 人口密度 も全国平均で 1.06 万人 $/ \mathrm{km}^{2}$ から 0.77 万人 $/ \mathrm{km}^{2}$ へと低 下傾向が続いている。

\section{3-2 市街地の規模と密度の変遷}

図一-1 は, 1960 年から 1975 年までの市街地人口と市 街地面積をそれぞれ常用効数でとり各市街地ごとにプロ ットしたものである。右上りの直線は市街地人口密度, 右下りの直線は市街化指数を表わしている。この図によ り日本に㧍けるすべての市街地を数量的に把握すること ができる。また図一 2 は市街化指数のランクごとに各年 度において市街化指数と市街地人口密度の平均を求めプ ロットしたものである。

まず図一1 を見ると点の分布が全体に年を追うごどに 右上方に伸び，市街地の規模の拡大傾向が続いているこ 


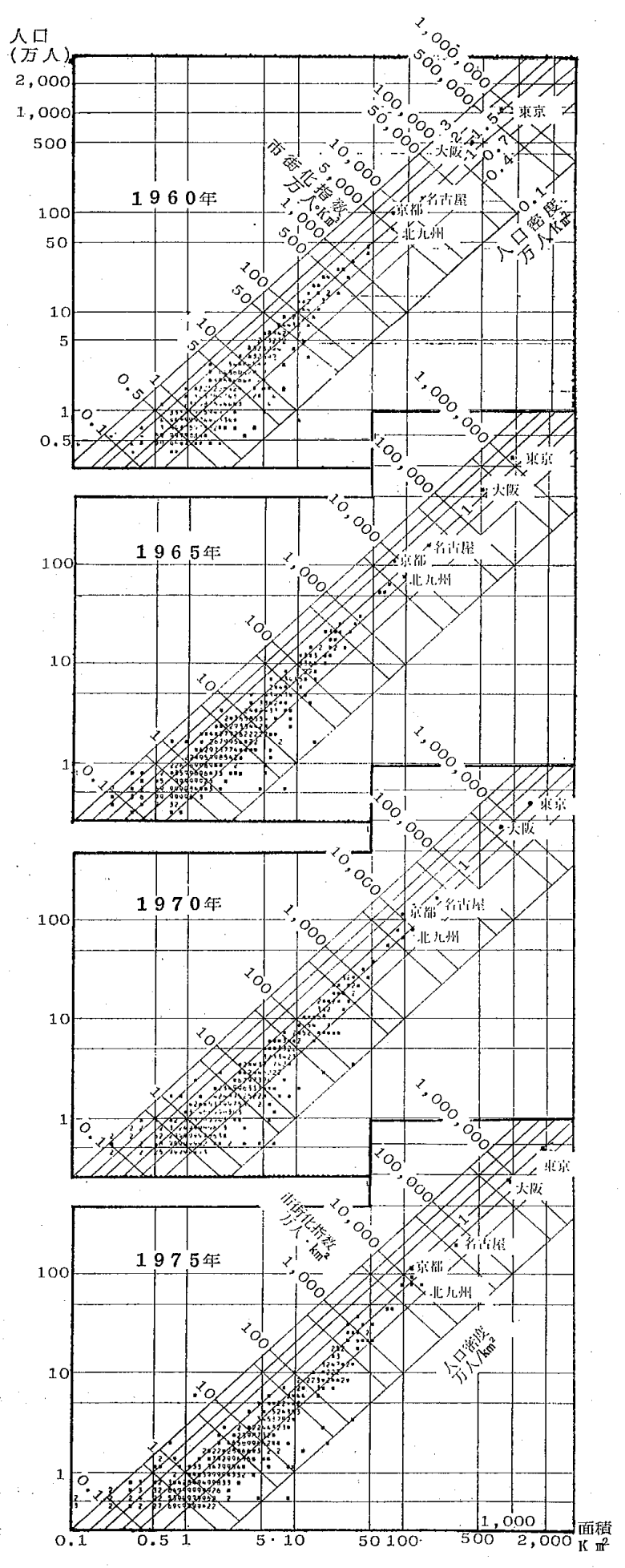

図一1 市街地（人口集中地区）の人口と面積

とがわかる。特に 1000 万人 $\mathrm{km}^{2}$ を上回る大規模な市 街地が増加している。また, 市街地人口密度は 1960 年 に掠いて 1 万人・ $\mathrm{km}^{2}$ の線を中心に分布していたがその 後急激な低下傾向を示し, 1975 年に 100 万人 $\cdot \mathrm{km}^{2}$ 以上 の比較的規模の大きい市街地では 1 万人 $/ \mathrm{km}^{2}$ を越える ものはほとんど存在しない。

次に市街地の規模と人口密度の関係注, 図一2による とほぼ比例関係にあり規模の大きい市街地ほど人口密度 は高いといら一般的傾向があるといえる。特に 1960 年 と'65 年潧著な傾向が見られ，またこの両年度におい

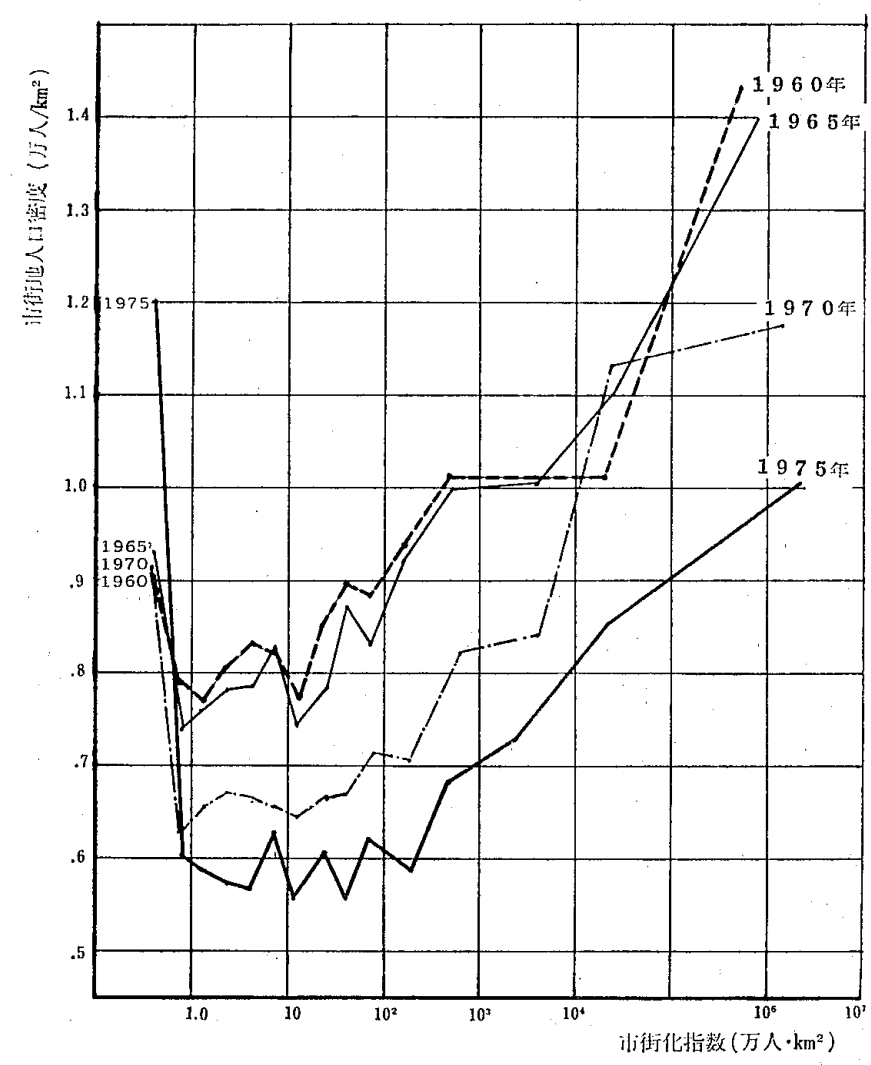

図一2市街地の規模と人口密度

て規模 と人口密度の対応関倸はほとんど变わっていな い。これが 1970 年には各ランクとも大幅な密度低下傾 向が表われ 1975 年においてもこの傾向は続いている。 これによって規模と人口密度の対応関係にも变化がみら れ，1975 年に抒いては 1 万人 $\cdot \mathrm{km}^{2}$ から 300 万人 $\cdot \mathrm{km}^{2}$ 程度の中小規模の市街地に扔いて人口密度が 6000 人・ $\mathrm{km}^{2}$ 前後の低密度な段階へ収敛する傾向がある。そして この間 $10^{2}$ 万人 $\cdot \mathrm{km}^{2}$ から $10^{3}$ 万人 $\cdot \mathrm{km}^{2}$ (市街地人口で 10 万人から 30 万人）のレベルと $10^{5}$ 万人 $\mathrm{km}^{2}$ を上回 る東京, 大阪巨大市街地に拈いて大幅な密度低下があっ たことがわかる。

さてここで特徴的なことは, 1965 年以降の市街地人 口密度の急激な低下であるが，これは主にこの時期にお きた市街地縁辺部での虫喰状の市街化により未成熟な 市街地が面的に大きく広がったためであると考えられ る注4)。特に，いわゆるミニ開発と言われる高密度な小 規模開発は，景観的には全く未成熟な市街地を DID に 組み入れる結果をむたらす。例えば 80 戸/ha の䪖度(300 人/ha）でのミ二開発なら，国勢調査区の 7 分の 1 が開発 され，住宅地化されたならば，全体で 40 人/ha の DID の基準を越えてしまう。即ち DID 縁辺部の市街地は, よく言われる「未利用空地や農地を多くかかえ込んだ末 成熟な市街地」といらより「高密度なミニ開発をシマ状 ・散落状にかかえ込んだ農業地帯」といった方が正確で ある。これでもグロスの密度で市街地の基淮をクリアす ることになる。 
さて以上のような未成熟な市街地形成は東京, 大阪, 名古屋などの巨大市街地の縁辺部で特に顕著に生じてお りこれが図一1に現われている $10^{4}$ 万人・ $\mathrm{km}^{2}$ 以上の 大市街地の飛躍的規模拡大の大きな原因と思われる。次

表一1 市街地の離合集散

\begin{tabular}{|c|c|c|c|c|c|c|c|c|}
\hline & & 1960 & & 1965 & & 1970 & & 1973 \\
\hline 単 & DID & 787 & & 878 & & 939 & & 978 \\
\hline 連 担 & DID & 20 & & 25 & & 49 & & 59 \\
\hline 発 & 生 & \multicolumn{3}{|c|}{173} & 266 & \multicolumn{3}{|c|}{219} \\
\hline 消 & 減 & \multicolumn{3}{|c|}{25} & 38 & \multicolumn{3}{|c|}{30} \\
\hline 接 & 合 & \multicolumn{3}{|c|}{61} & 143 & \multicolumn{3}{|c|}{136} \\
\hline 一 体 & 化 & \multicolumn{3}{|c|}{5} & 7 & \multicolumn{3}{|c|}{10} \\
\hline 分 & 割 & \multicolumn{3}{|c|}{0} & 4 & \multicolumn{3}{|c|}{36} \\
\hline
\end{tabular}

表一2.大市街地の規模と密度

\begin{tabular}{|c|c|c|c|c|c|c|}
\hline 市 & 街 & 地 & $\begin{array}{l}\text { 市街化指数 } \\
\left(\text { (万人 } \cdot \mathrm{km}^{2}\right)\end{array}$ & $\begin{array}{l}\text { 市街地人口 } \\
\text { (万人) }\end{array}$ & $\begin{array}{c}\text { 市街地面積 } \\
\left(\mathrm{km}^{2}\right)\end{array}$ & $\begin{array}{c}\text { 人口密度 } \\
\left.\text { (万人 } / \mathrm{km}^{2}\right)\end{array}$ \\
\hline \multicolumn{7}{|c|}{1960 年 } \\
\hline 1 & 東 & 京 & 786591.9 & 1073. 27 & 732.9 & 1.464 \\
\hline 2 & 大 & 服 & 239544.5 & 579.04 & 413.7 & 1.400 . \\
\hline 3 & 名 古 & 屋 & 20223.9 & 150.15 & 134.7 & 1.115 \\
\hline 4 & 京 & 都 & 8906.6 & 113.75 & 78.3 & 1.453 \\
\hline 5 & 北 九 & 州 & 5974.9 & 77.91 & 76.7 & 1.016 \\
\hline 6 & 札 & 㬐 & 2357.4 & 49.63 & 47.5 & 1.045 \\
\hline 7 & 福 & 岡 & 2167.0 & 49.94 & 43.4 & 1.151 \\
\hline 8 & 広 & 島 & 2001.7 & 42.68 & 46.9 & 0.910 \\
\hline 9 & 訨 & 台 & 1108.5 & 33.60 & 33.0 & 1.018 \\
\hline 10 & 浦 & 和 & $781: 5$ & 27.82 & 28.1 & 0.990 \\
\hline \multicolumn{7}{|c|}{1965 年 } \\
\hline 1 & 東 & 京 & 1251916.0 & 1320.04 & 948.4 & 1.392 \\
\hline 2 & 大 & 阪 & 336456.8 & 690.31 & 487.4 & 1.416 \\
\hline 3 & 名 古 & 屋 & 26310.9 & 170.85 & 154.0 & 1.109 \\
\hline 4 & 京 & 都 & 8934.4 & 115.74 & 77.2 & 1.499 \\
\hline 5 & 北 九 & 州 & 8296.2 & 86.79 & 95.6 & 0.908 \\
\hline 6 & 札 & 缐 & 4660.8 & 66.88 & 69.7 & 0.960 \\
\hline 7 & 福 & 岡 & 3489.2 & 61.01 & 57.2 & 1.067 \\
\hline 8 & 広 & 島 & 3381.5 & 55.80 & 60.6 & 0.921 \\
\hline 9 & 仙 & 台 & 1307.2 & 37.75 & 35.0 & 1.067 \\
\hline 10 & 浦 & 和 & 1066.1 & 31.55 & 33.8 & 0.933 \\
\hline \multicolumn{7}{|c|}{1970 年 } \\
\hline 1 & 東 & 京 & 2129745.6 & 1578.77 & 1349.0 & 1.170 \\
\hline 2 . & 大 & 阪 & 668534.8 & 890.43 & 750.8 & 1.187 \\
\hline 3 & 名 古 & 屋 & 38069.6 & 188.66 & 201.8 & 0.935 \\
\hline 4 & 京 ” & 都 & 10754.1 & 119.50 & 90.0 & 1.328 \\
\hline 5 & 北 九 & 州 & 9440.0 & 85.74 & 110.1 & 0.779 \\
\hline 6 & 福 & 岡 & 7091.0 & 77.17 & 91.9 & 0.840 \\
\hline 7 & 札 & 愰 & 6911.2 & 80.28 & 86.1 & 0.932 \\
\hline 8 & 広 & 島 & 4130.2 & 62.40 & 66.2 & 0.943 \\
\hline 9 & 仙 & 台 & 2352.5 & 44.81 & 52.5 & 0.854 \\
\hline 10 & 熊 & 本 & 1442.7 & 34.69 & 41.6 & 0.834 \\
\hline \multicolumn{7}{|c|}{1975 年 } \\
\hline 1 & 東 & 京 & 3678126.4 & 1926.73 & 1909.0 & 1.009 \\
\hline 2 & 大 & 阪 & 861408.6 & 966.03 & 891.7 & 1.117 \\
\hline 3 & 名 古 & 屋 & 62105.2 & 223.41 & 278.0 & 0.804 \\
\hline 4 & 甞 & 都 & 16226.0 & 134.22 & 120.9 & 1.110 \\
\hline 5 & 北 九 & 州 & 12382.5 & 92.21 & 134.3 & 0.687 \\
\hline 6 & 福 & 岡 & 10861.2 & 93.48 & 116.2 & 0.804 \\
\hline 7 & 札 & 幌 & 10828.9 & 96.61 & 112.1 & 0.862 \\
\hline 8 & 広 & 島 & $7627: 0$ & 79.79 & 95.6 & 0.835 \\
\hline 9 & 静 & 阊 & 3939.6 & 52.82 & 74.6 & 0.708 \\
\hline 10 & 仙 & 台 & 3761.9 & 53.36 & 70.5 & 0.757 \\
\hline
\end{tabular}

節ではこれら規模执大の顕著な十大市街地を例にとり市 街地規模の应大とこれに併ら人口密度の関連を分析寸 る。

\section{3-3 十大市街地の規模と密度}

表一2 は市街化指数を尺度とした各年度の市街地の諸 元を示したものである。まず，1960 年の時点に招ける 状況は, 市街化指数が $10^{5}$ 万人 $\cdot \mathrm{km}^{2}$ を上回る東京, 大 阪の巨大連担市街地とそれ以外の大市街地に大別するこ とができる。前者が 1.4 万人 $/ \mathrm{km}^{2}$ を上回る人口密度を 有するのに対して後者は 1 万人 $/ \mathrm{km}^{2}$ 前後の密度となっ ている。後者の中で京都は例外で東京, 大阪巨大連担市 街地に匹敵する密度となっているが，これは整備された 街割りに沿って町屋を中心とした高密度でコンパクトな 市街地が歴史的に形成されてきたためと考えられる。そ して十大市街地に打ける東京, 大阪, 京都の高密度のグ ループとこれより 2〜3 割密度の低いグループの閒には 1975 年時点に招いても, その差を若干縮めながらも明 確な差が存在している。

さてこれらの大市街地が 1960 年から 1965 年にかけ て人口密度をほぼ同程度に保ちながら成長しているのは 前節で述べたとおりである。そして 1970 年，1975 年に 沶いて急激な規模の拉大に併い人口密度を大幅に低下さ せ 1975 年の時点で, 東京, 大阪, 京都が 1 万人 $/ \mathrm{km}^{2}$ から 1.1 万人 $/ \mathrm{km}^{2}$, その他の市街地が 8 千人 $/ \mathrm{km}^{2}$ 前後 の值となっている。そして 1975 年の時点では, 東京を 抜いて大阪が，1.1万人 $/ \mathrm{km}^{2}$ という最も高密度な連担市 街地を形成している。

次に市街化指数でみた市街地の規模の順位は 1 位東京 から 8 位広島まで変わっていない。この中で北九州の成 長が他と比べて著しく小さく人口規模は 1960 年の 5 位 加ら 1975 年には 7 位に転落し，人口密度も 6 千人 $/ \mathrm{km}^{2}$ 台で他と比べ低い值となっている。これは北九州連担市 街地に装置型の大規模工業地帯とそれに倸わる港湾など の流通基地など人口以外の都市の装置が多く集積してい るためでここれらの要因が市街地面積として含まれる市 街化指数で浪北九州は依然として第 4 位の規模を保って いる。

いずれにしてもこの 15 年間に北九州を除く日本の 10 大市街地は人口，面積ともほぼ倍堌させ，これらの市 街地への人口の集積がきわめて著しかったことを示して いる。

さてこのように拡大する巨大市街地は他と比べてきわ めて特異な過程を経ているものと考えられる。次節にお いてこれら巨大市街地の拡大過程について分析を行な 5 。

\section{3-4 十大市街地の拡大過程}

さて市街地の拡大過程は, 模式的に図一 3 に示した 3 つのタイプにより示すことができる。 
衰一3 10 大市街地の拢大過程

\begin{tabular}{|c|c|c|c|c|c|c|c|c|c|}
\hline & & & \multicolumn{2}{|c|}{ 市街地人口（万人） } & \multicolumn{2}{|c|}{ 市街地面積 $\left(\mathrm{km}^{2}\right)$} & \multirow{2}{*}{$\begin{array}{r}\mathrm{A}\left(\mathrm{km}^{2}\right) \\
(\%)\end{array}$} & $\mathrm{B}\left(\mathrm{km}^{2}\right)$ & \multirow{2}{*}{$\begin{array}{r}\mathrm{C}\left(\mathrm{km}^{2}\right) \\
(\%)\end{array}$} \\
\hline & & & 1975 & 1960 & 1975 & 1960 & & $(\%)$ & \\
\hline 1 & 東 & 京 & 1926.73 & 1208.12 & 1909.0 & 901.6 & $732.9(38.4)$ & $1008.3(52.8)$ & $167.8(8.8)$ \\
\hline 2 & 大 & 阪 & 966.03 & 617.27 & 891.7 & 459.5 & $413.2(46.4)$ & $432.2(48.5)$ & $45.8(5.1)$ \\
\hline 3 & 名 古 & 屋 & 223.41 & 160.45 & 278.0 & 146.8 & $134.4(48.5)$ & $131.2(47.2)$ & $12.1(4.4)$ \\
\hline 4 & 京 & “都 & 134.22 & 113.75 & 120.9 & 78.3 & $78.3(64.8)$ & $42.6(35.2)$ & $0.0(0.0)$ \\
\hline 5 & 北九 & 州 & 92.21 & 83.02 & 134.3 & 82.3 & $76.7(57.1)$ & $52.0(38.7)$ & $5.6(4.2)$ \\
\hline 6 & 福 & 岡 & 93.48 & 53.64 & 116.2 & 49.0 & $43.4(37.4)$ & $67.2(57.8)$ & $5.6(4.8)$ \\
\hline 7 & 札 & 愰 & 96.61 & 49.63 & 112.1 & 47.5 & $47.5(42.4)$ & $64.6(57.6)$ & $0.0(0.0)$ \\
\hline 8 & 広 & 島 & 79.79 & 44.98 & 95.6 & 50.6 & $46.9(49.1)$ & $45.0(47.1)$ & $3.7(3.4)$ \\
\hline 9 & 静 & 岡 & 52.82 & 35.52 & 74.6 & 33.9 & $18.9(25.3)$ & $40.7(54.6)$ & $15.0(20.1)$ \\
\hline 10 & 仙 & 台 & 53.36 & 33.60 & 70.5 & 33.0 & $33.0(46.8)$ & $37.5(53.2)$ & $0.0(0.0)$ \\
\hline
\end{tabular}

（注） 1) 人口，面積とも 1975 年度の市街地の籁囲に呫ける各年度の市街地人口，市街地面積を表わしている。

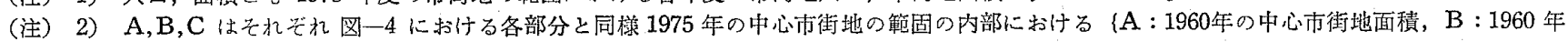
洔点の未市街地面積，C：1960 年に中心市街地から独立して存在していた市街地の面積\}を表わしている。

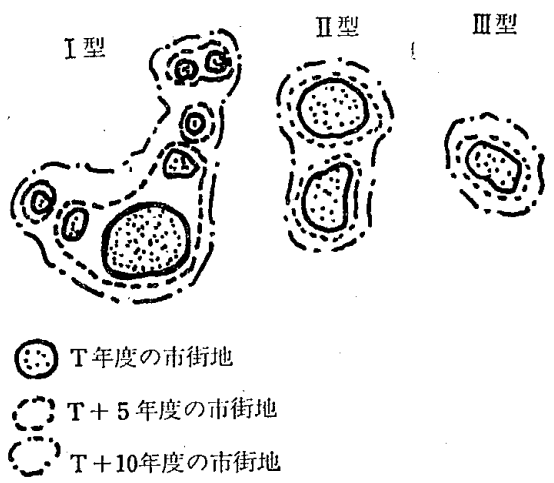

图一－市街地の扩大過程。

I 型は東京，大阪，名古屋などの巨大連担市街地に典 型的に見られる拡大過程で，核になる巨大市街地が周辺 に存在する睡存の中小の市街地を包み込むよらにして拉 大していく。ா型は同程度の市街地が相互に成長し接近 し連担することを示している。III型は最も一般的な市街 地の㹡大過程で既存の市街地を吸収することなく, 周辺 農村集落などを包み込みながら市街地が徐々に桩大する 型である。

さてI型の典型である東京巨大連担市街地の 1960 年 以降の拉大過程を追ってみよう。東京連担市街地の 1960 年における市街地面積は，まだ $732.9 \mathrm{~km}^{2}$ であったが， 1975 年には $1909 \mathrm{~km}^{2}$ となり，1176.1 km² の面積の增 加を示している。しかし，この $1176.1 \mathrm{~km}^{2}$ がこの 15 年の間に新たに市街化されたのではなく，この中のある 部分は 1960 年の時点ですでに, 東京連担市街地とは独 立に市街地として存在していたのである。表一3 はこの ような実態を把握するため，1975 年の時点で連担市街 地を形成している地理的範囲において，それ以前の各時 点において市街地形成されていた面積とそこにおける人 口を示したものである。たとえば東京に掠いては 1975 年時点における連担市街地の範囲において 1960 年に市 街地形成されていたのは，901.6 km² であったことがわ かる。これを図示したのが図一4であり図一4の各部分 の面積とその比率を求めたのが表一3の後半である。こ れより 1975 年に捛ける東京連担市街地のうち 1960 年
(B) 1960 年か 51975 年に新てに 形成された市街地】

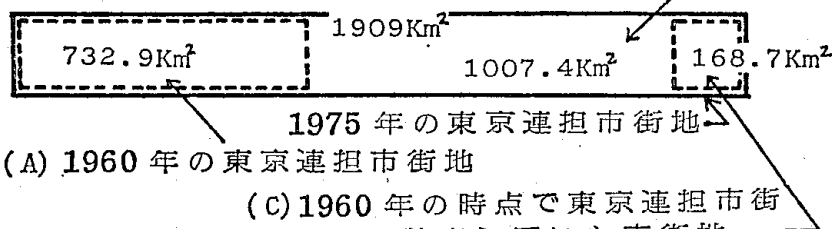

地か 5 独立してい行市街玏

图一4 東京巨大連担市街地の拡大過程

において連担市街地を形成していた地域の面積は全体の $40 \%$ 弱で $50 \%$ 強にあたる面積がこの閒 15 年に市街地 に新たに加えられたことがわかる。

さて表一3より 1960 年加ら 1975 年に至る 10 大市街 地の拡大過程をみるとI型が東京, 名古屋, 大阪, 広 島, 北九州, 福岡, II型方静岡, III型が京都, 札幌, 仙 台といらことになる。I型では 1975 年を全体としたと き1960年時点に和ける連担市街地面積はほぼ40〜50\%， 1960 年時点で独立して市街地形成していた部分の面積 は $5 \%$ 前後で, 残りの $50 \%$ 前後が 1960 年から1975 年 に新たに市街化されたことになる。この中でも東京は新 たに市街化された部分が多く，特に急激な市街化がなさ れ，逆に北九州は他と比べて，拡大テンポが緩やかだっ たことがわかる。II型，亚型である静岡，京都，札幌， 仙台もI 型同様面積的には，1960 年の市街地面積を倍 増し急激な市街化がなされたことがわかる。そして北九 州を除くいずれの市街地も人口の上からも市街地人口を 1.5 2 倍に延ばしている。このよらにさまざまな形学 とりながらも，1960年から 1975 年にかけて日本におけ る十大市街地は非常な勢いで拡大したといらことができ よう。

\section{4. 市街地の変動過程 \\ 4-1 市街地変動の概観}

これまでの分析により 1960 年から 1975 年までの間 に市街地はその規模と密度をさまざまに変化させている ことが明らかになったが，本章ではこのよらな市街地の 変動寸る過程を前述の市街化指数変化率と市街地人口密 
度化率の 2 指標の組合せによっ て表現しさらに詳細な分析を行 なら。図一5，図一6 はそれぞ れ 1960 年加ら 1965 年 (以下

「第1期」と略す)，1960 年加 ら 1970 年 (同「第 2 期」),1970 年加ら 1975 年 (同「第 3 期」) の 3 期閒について, 個々の市街 地の市街化指数变化率と市街地 人口密度変化率地方別, 規 模別にプロットしたものであ る。これにより市街地の規模と 密度がどのよらな関連で変動し ているかを知ることができる。 さらに表一 4 注北日本(北海道， 東北，北陸），中部日本 (関東， 中部, 近畿), 南日本 (中国, 四国，九州）の 3 ブロックごと に規模により市街地を区別し， この区分ごとに市街化指数変化 率と市街地人口密度変化率をク ロスさせ相対度数を求めたもの である。これらの図表により， それぞれの時期における市街地 の変動が，市街地の国土全体の 中に打ける立地条件や市街地の 規模などと，どのように関連し ていたかを知ることができる。 まず図一5より全国ベースで みると第 1 期に比べ，第 2 期の 点の分布が左上に移動し，第 2 期に抒いて市街地人口密度の低 下を伴なう市街地規模の拡大が なされたことがわかる。そして 第 3 期に掠いて，いくぶルこの 勢いはおさまってはいるが，大 部分の市街地で注, 市街地人口 密度の低下をともなら規模の拡 大といら傾向が定着したようにみえる。特に関東地方,近 畿地方ではこの傾向が顥著であり規模別では 2 ランク， 3ランクにこの傾向がみられる。

次に市街地の変動を地方別にみると, 北日本, 南日本 と関東, 中部, 近畿の間で市街地変動に関して顕著な差 異が認へられ次の事項が明らがなった。

(1) 南日本, 北日本では規模が縮小し, 密度が減少し ていく衰退傾向の市街地が数多く存在する。特に第 1 期 において市街化指数変化率が大幅に 1 を下回り，規模が 著しく縮小している市街地が多く存在する。これは規模

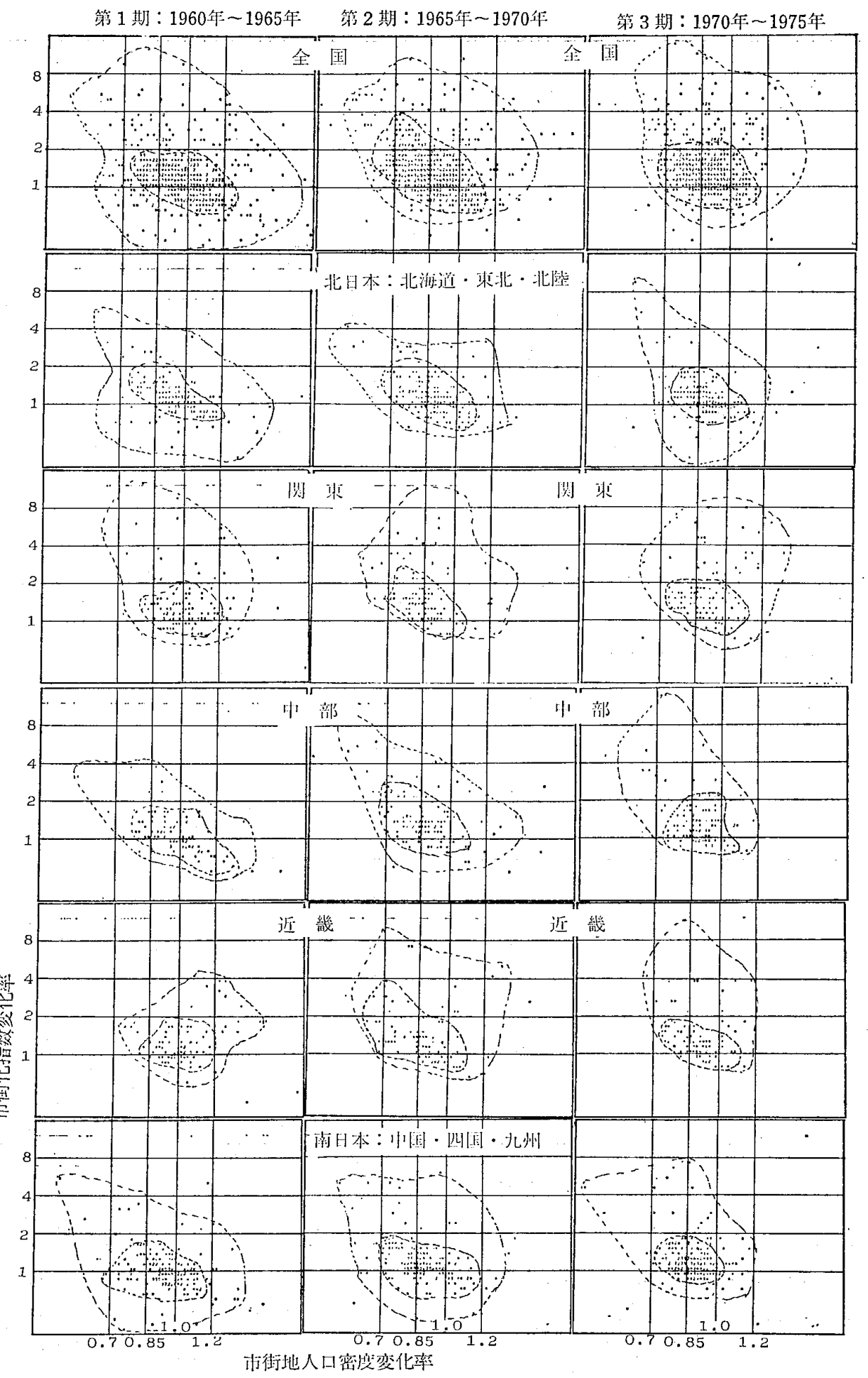

图一5 地方別にみた市街地の変動

で1，2 ランクに集中していることが表一4によりわか る。第 2 期以降このような急激な規模の縮少を示す市街 地沙減少している。

(2) 第 1 期においては規模が縮少する反面市街地人口 密度が高まる市街地が多く存在するが，北日本，南日本 では特に多く第 2 期, 第 3 期に沶いても多く存在してい る。これは市街地縁辺部において人口流出が起き，市街 地の中で相刘的に人口密度が低い部分が市街地から脱落 したためと考えられる。

(3) 第 2 期以降関東, 中部, 近畿に㧍いては分布が上 
表一4 地方別・規模別にみた市街地の変動過程(家)

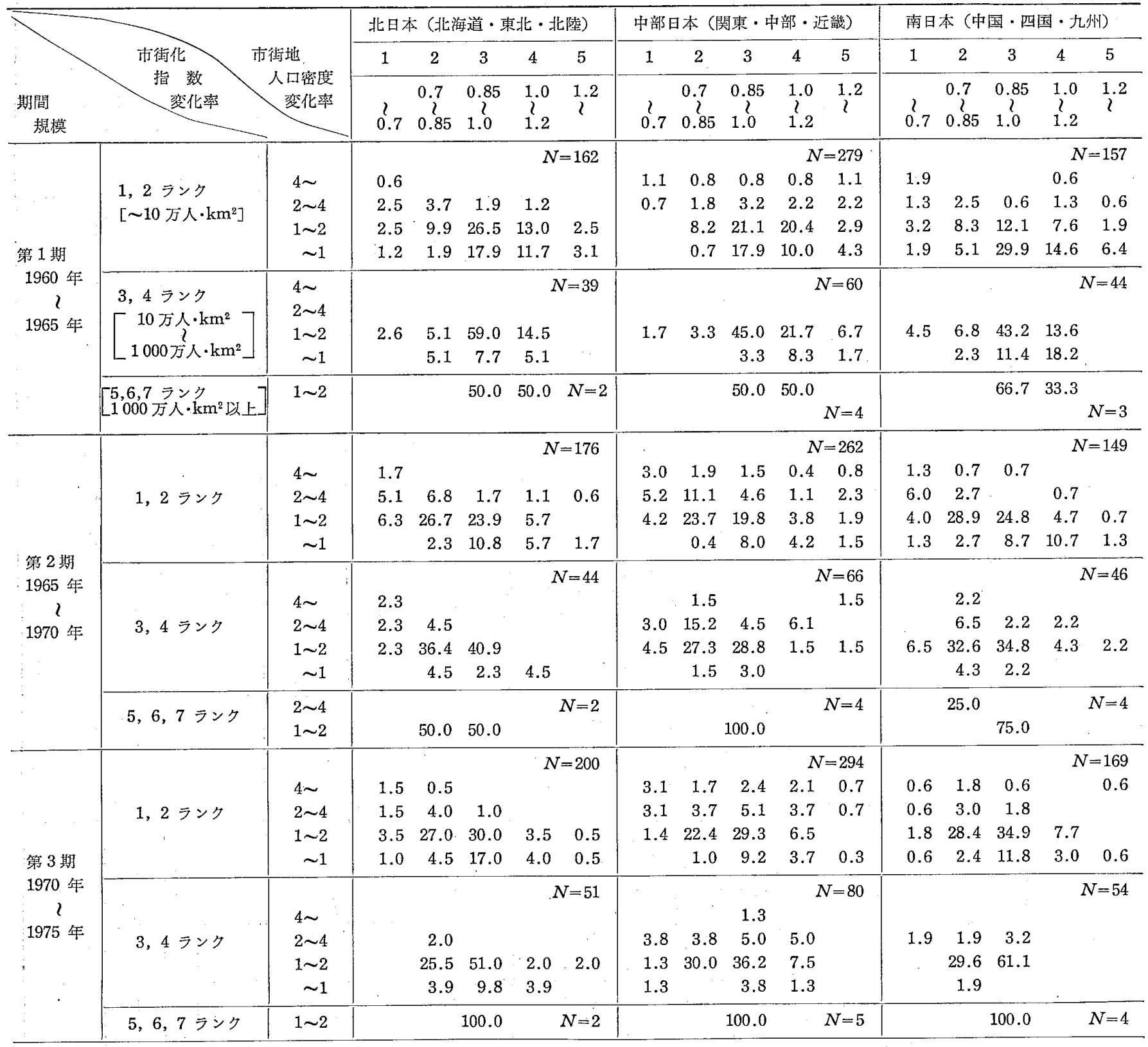

方に広がり，急激な搪大をした市街地があったことを示 しているが，これに比へ，北，南日本では分布が下方に あり，また中心にかたまる傾同にあり，多くの市街地が 搪大傾向は小さく，おだやかな市街地変動をしているこ とがわかる。

(4) 関東・近畿においては第 1 期には市街地人口密度 の高密化をともなら規模の拡大をする市街地が数多く存 在したが，第 2 期で非常に減少し，第 3 期に多少増加し ている。特に第 2 期において規模を报大した市街地はほ とんど密度が低下している。

次に図一6より市街地規模により市街地の変動過程を 分析する以下のことが明らかになった。

(1) $1 ， 2 ， 3$ ランクの市街地においては 3 期を通じて 密度，市街化指数とも低下乙て衰退化傾向にある市街地 が数多く存在する。特に第 1 期において 1,2 ランクでは 急激な衰退をしたものが存在した。これに対して4ラン
ク以上の市街地にはこのような衰退傾向の市街地はほと んどない。すなわち市街化指数 100 万人 $\mathrm{km}^{2}$ を越える 規模に市街地が成長すると以後規模が縮小することほほ とんどないといえよう。

(2) 2 ランク以上の市街地においては第1期から第 2 期にかけて明らかに点の分布が左上方に移動し，低密度 化をともなら市街地規模の増大といら傾向が強まったこ とを示している。特に 4ランク以上の市街地では, 市街 地人口密度が高密化しているものはほとんど存在せず低 密化をともなら規模の桩大というのが一般的傾向となっ ている。

(3) これに対し，1，2，3 ランク，特に 2 ランクの市 街地で海第 1 期とともに第 3 期においても市街地人口密 度が高密化しながら規模を拡大している市街地が数多く 存在する。これ第 2 期に空地を多くかかえ込んで市街 化した周辺部に，第 3 期において空地を充填する住宅地 
化が進んだためと考えられる。 このように中小規模の市街地に おいては密度を高めながら市街 地が成長するといらパタンが存 在しているといえる。

以上の分析より市街地の規模 によりその変動過程にきわめて 明確な差異が生じていることが わかる。

4-2 市街地変動過程の 類型 化とその分布

前節では市街地変動における 市街地の規模と密度の関連を概 観したが，ここでは変動過程と いう視点から市街地を類型化 し，1960 年加ら 1975 年の時間 と日本国土といら空間の中でそ れらがどのように分布していた かを明らかにする。

まず市街地は規模の衰退，成 長といら視点から以下の 3 つの 型に分類することができる。

(1) 衰退型市街地（市街化指 数変化率が 1.0 未満)

(2) 安定成長型市街地（市街 化指数変化率が 1.0 以上 2.0 末満)

(3) 急成長型市街化（市街化 指数変化率が 2.0 以上）

（1）衰退型市街地とその分 布

市街化指数変化率が 1.0 未満 で市街地の規模が縮小傾向にあ るのがこの衰退型市街地でほと んどが $10^{2}$ 万人 $\cdot \mathrm{km}^{2}$ 以下の規 模であり一般に規模が小さいほ ど衰退型市街地の割合が高い。 特に，第 1 期に扔いて各地方と も多く存在しており，地方别で は北日本, 南日本に多く, 中部日本には少ない。

さて南日本に扔いて恃特第 1 期に多く存在し 10 万 人 $\mathrm{km}^{2}$ 末満では約半数に達している。しかし第 2 期以 降この割合は急激に減少し, 第 3 期には中部日本と同程 度の構成比となっている。

これに対し北日本は第 1 期において，各ランクとも衰 退型市街地の割合注南日本の半数程度であったのが第 2 期において多少減少するが，第 3 期には逆に増加する傾 向が表われている。特に第 3 期に㧍いても規模，密度と

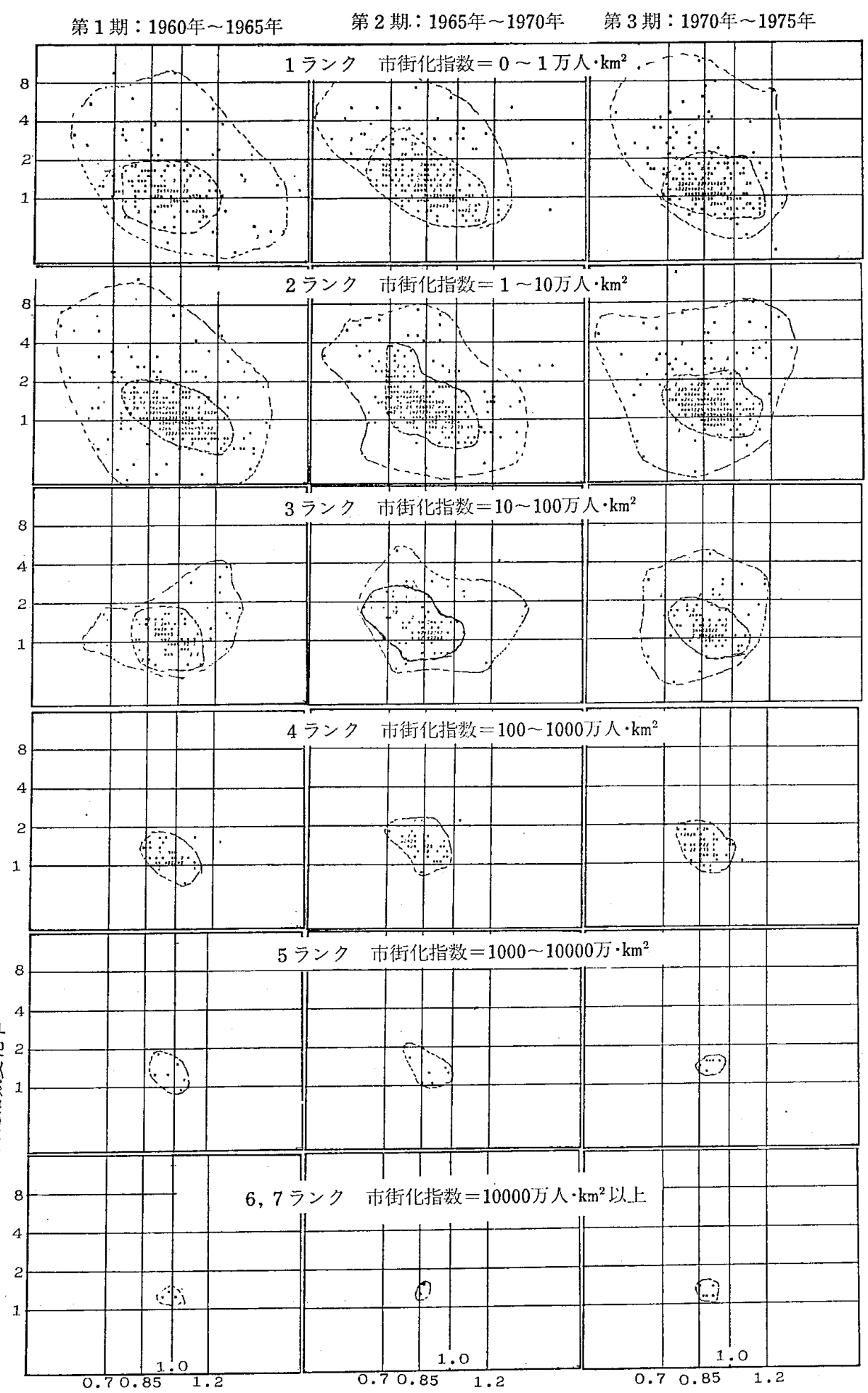

书街地人口密度変化率

図一6規模別にみた市街地の変動

む減少する完全な衰退型市街地が 1，2 ランクでは $20 \%$ を越えていること， 1, 2 ランク (10 万人・ $\mathrm{km}^{2}$ 末満) だけ でなく 3,4 ランク $\left(10\right.$ 万人 $/ \mathrm{km}^{2}$ 以上 $10^{3}$ 万人 $\cdot \mathrm{km}^{2}$ 未満）に打いても $15 \%$ 程度が衰退型市街地であること が特徵的である。

以上の上うに衰退型市街地の分布からみると北日本と 南日本で明らかな差が生じている。これは南日本におい て，太平洋ベルト地域に含まれる瀬戸内海沿岸に扮い $\tau, 1960$ 年代以降新産業都市, 工業整備特別地域など 
による産業基盤整備が淮行したこと，北日本が積雪寒冷 地域といら宿命的風土を背抽っていることなどがその要 因と考えら机る。

次に東海道ベルト地带をかかえる中部日本について分 析を行なう。ここにおいても第 1 期は $1 ， 2$ ランクで約 30\%が衰退型市街地である。これはこの時期の急激な太 平洋ベルト地带への集積により北関東や中部内陸地域に おいて小規模市街地が衰退化したためと思狈机第 2 期以 降半減している。特に 3,4 クンクおよびそれ以上の規模 の市街地では第 2 期以降衰退型市街地はほとんど存在せ ず，中部日本の市街地は規模の抾大が一般的傾向となっ ている。

さて，このような衰退型市街地の分布をむとめると， 第 1 期に执いて各地方とも多く存在していた衰退型市街 地が第 2 期に扮いて中部日本, 第 3 期に捛いては南日本 において減少し, 北日本に执いては依然として多く存在 しているといえる。

\section{（2）安定成長型市街地とその分布}

安定成長型市街地（以下，単に「成長型市街地」と 略）とは市街化指数変化率が 1.0 以上 2.0 未満で安定 的な成長過程にある市街地である。これは人口密度の増 減により, 市街地人口密度変化摔が 1.0 未满の低密化成 長型市街地と 1.0 以上の高密化成長型市街地に大別での きる。成長型市街地の分布は衰退型市街地分布と表裹の 関係にあり，概略以下のことが言える。

(1) 各地域とも各時期, 各規模において成長型市街地 が最も大きな割合を示しているが，中部日本では第 2 期 以降, 南日本では第 3 期以降その割合をさらに高めてい る。

(2) $10^{2}$ 万人 $\cdot \mathrm{km}^{2}$ 以上の市街地は後述する急成長型 を含めれば，ほとんどが成長型市街地といえる。

(3) 第 2 期以降, 成長型市街地に打ける低密化傾向が 定着し，低密化成長型市街地の割合が急増した。

このような傾向を持つ成長型市街地を各地方ごとに以 下分析を行なら。

まず最も成長型市街地の多く分布する中部日本では, 1960 年から 1965 年までの第 1 期においては高密化成長 型市街地が多数存在していた。すなわち成長型市街地の らち 1,2 ランクでは半数， 3,4 ランクでは $30 \%$ 程度を 占めていた。これが第 2 期になると激減し, 市街地人口 密度変化率が 0.85 を下回り急激な密度低下したものが 各ランクとも 30 ４0\% 存在し，低密化成長型市街地が 大部分を占めるよらになる。そして第 3 期においてもこ の傾向は若干弱まりながらも定着したように思われる。

次に南日本においては, 第 1 期に成長型市街地の占め る割合が極端に小さく 1,2 ランクでは半数にも満たなか った。これが第 2 期, 第 3 期と成長型市街地が増加し, 第 3 期においては 3,4 ランクのほとんどが成長型に属す
るなど，全般的に成長傾向が定着したといえよう。

これに対し北日本では第 2 期において多少増加する が，第 1 期と第 3 期において成長型市街地の占める割合 はほとんど増加せず, 南日本とこの 15 年の間に成長型 市街地の比率に㧍いて完全に逆転している。さらに第1 期において 1,2 ランク，3,4 ランクとも $15 \%$ 以上存在 した高密化成長型市街地が第 2 期以降ほとんどみられ ず, 成長型市街地におうる低密化傾向は他地域以上に顕 在化している。

(3) 急成長型市街地

市街化指数変化率が 2.0 以上の急成長型市街地は 1965 年からの第 2 期以降中部日本に大量に発生する。すなお ち，第 2 期に执いて $1 ， 2$ ランク，3，4 ランクともに $30 \%$ ，第 3 期江扮いても $20 \%$ 以上が急成長型市街地と なっており，いずれむ他地域の 3 倍程度の比率となって いる。すなおち国土全体で市街地が大きく変動する 1965 年から 1975 年において急成長型市街地の分布は大きく 中部日本に偏っており，このような急激な市街地成長を もたらすポテンシャルは中部日本に偏在していたといえ よう。

\section{5. 時期区分よりみた市街地の変動}

本編においては, 市街地の変動過程を時期別, 地方 別, 規模別に分析を行ない, その実態を一応明らかにす ることができた。ここでは分析に用いた 3 期をむとにこ れらの結果を要約する。

まず， 3 期の特徴をむとめると以下のごとくである。

(1) 第 1 期は全般的に市街地の変動が小さく, 中部日 本を除く地域, 特に南日本においては多くの市街地が衰 退化傾向を示し，全国的にみて第 2 期以降に生じる急激 な変動に備える胎動期であったと言える。

(2) 第 2 期は全般的に急激な市街地成長が始まる時期 であり成長型市街地における市街地人口密度の急激な低 下が全国的に定着した。しかし依然しして北日本, 南日 本に打いては市街化指数 10 万人 $\cdot \mathrm{km}^{2}$ 末满の小規模な 市街地ではかなりの割合 (20\% 強) が衰退化傾向を示し ている。

(3) 第 3 期は第 2 期における急激な市街地搪大の傾向 が多少弱まり収㪘期であるといえる。そして南日本にお いて衰退型市街地が激減する一方, 北日本に就いては依 然, 中小規模の市街地においてかなり衰退化傾向を示す ものが存在する。

さてこのような 1960 年から 1975 年までの 3 期にわ たる市街地变動の実態は日本の社会経済的状況と対比さ せてみれば明らかな符合を読みとることができる。すな わち第 1 期は 1960 年に閣議決定した所得倍堌計画の前 期にあたり太平洋ベルト地域に急激な公共投資が行なわ れ, 東京, 大阪, 名古屋の 3 大都市圈に局所的な人口集 積が生じた時期である。表一2 によれば第 1 期において 
これら大市街地は急激な市街化指数の増大にかかわらず 市街地人口密度を一定の水準に保って招り，第 2 期以降 ときわだった対照を示している。一方この裹の現象とし て 3 大都市圈から遠く隔たった南日本や北日本だけでな く，中部日本に扔いても中小規模の市街地で衰退化傾向 を示すむのが多く存在し，過密過柾対策が次の政策課題 となる。

そして第 2 期は大都市問題, 過密過柾問題が深刻化 し，新全国総合開発計画 (1967 年)により集中から分散 へと政策的にも転換がはかられる時代である。この時期 は 3 大都市圈の人口集積が波及し，中部目本において急 成長する市街地が多数現われる。一方，第 1 期において 多くの衰退型市街地をかかえる南日本は，太平洋ベルト 地域の一部を成す瀬戸内海沿岸への産業基盤の集積を反 影し，大きく回復のきざしを見せてはいるが，北日本と ともに依然として多数の衰退型市街地をかかえている。

さて，1970 年から始まる第 3 期は太平洋べルト地域 への集積が一段落し, 経済政策も 1973 年のオイルショ ックを境に高度成長加ら安定成長一転換し, 国土計画に おいても地方定住に向けて様々な検討がなされ大きな変 曲点となった時期である。そして現実のこの期の市街地 変動は南日本において衰退型市街地が激減したのに対 し，北日本ではむしろ増加傾向をみせ，この両地域で大 きな差が生じている。また中部日本では急成長型が若干 減り高密化成長型が多くなり，外延的桩大から内部充実 に向から収斂傾向が現われている。

さて，このように 1960 年から 1975 年までの市街地 の変動を分析すると，1960 年代初頭に選択された所得 倍増計画に伴なら太平洋ベルト地域構想と，それに続く 全国開発計画，新全国総合開発計画は，1975 年の時点 において，中部日本において大きな市街地の成長をもた らし南日本に抒いて市街地の衰退を喰い止めはしたが, 北日本においては低然として明確な效果を就よぼしてい ないといえよう。

\section{5. まとめと今後の展開}

本編は 1960 年から 1975 年までの市街地の密度と規 模の変動を全国的な視野で概観するにとどまっている。 本編にお汸結論注以下の点に集約できる。その第 1 は 1960 年から 1975 年までの 3 期間は市街地変動に関し明 確な特徴を持っていたといらことである。第 1 期は 3 大 市街地とその周辺のみに人口が集積し全般的に市街地変 動が小さく次期の急激な変動にそなえるいわば胎動期で あった。そして第 2 期は急激な拉大期で, 特に市街地人 口密度の急激な低下を伴なう掂大がこの期の特色であ る。これに続く第 3 期は収敛期で第 2 期の勢いを緩めな がら, 低密度に拡大した市街地の内部充填し, 高密化 しながら成長する市街地が増加している。このようなお おまかな時期を区分できた。
第 2 にこのような時期区分は市街地の成長ポテンシャ ルの各地への波及と期を一にしている。すなわち第 1 期 は 3 大市街地周辺に大きな成長ポテンシャルが生じ，第 2 期注大都市圈を中心とする中部日本へ，第 3 期は太平 洋ベルト地域の一部を成す瀬戸内海を含先南日本へそれ ぞれ市街地成長ポテンシャルが波及していると言えよ う。そして北日本は 1975 年の時点ではまだ数多くの衰 退型市街地をかかえ市街地成長のポテンシャルが十分に 生じているとは言えない。

結論の第 3 汢市街地の規模によりその変動が影響をう けているという点である。すなわち 10 万人・ $\mathrm{km}^{2}$ 以下の 市街地では急激に成長する市街地がある反面衰退型市街 地も多く，あらゆる変動が可能であるのに対し，100 万 人・ $\mathrm{km}^{2}$ 以上の市街地は穏かな成長過程をとり衰退する ことはまれである。そして 10 万人・ $\mathrm{km}^{2}$ から 100 万人・ $\mathrm{km}^{2}$ の市街地は両者の中間的意味を持つ規模であると言 えよう。

以上の結果をふを元て今後以下の分析を行なう。

(1) 個々の市街地の変動過程をより詳細に類型化し, 各地方に执いてその地理的分布とその変化を明らかにす る。

(2) それぞれの市街地において類型化されたパタンが 3 期間（1960 年から 1975 年）にわたってどのように変 化したかを分析し，市街地変動のメカニズムを明らかに する。

(3) 市街地の変動過程がそれぞれの市街地の規模や地 理的条件とどのような関連にあるかを分析する。

最後に作業の過程で早大戸沼研究室において多大な苏 力を下さった中沢一夫君（現在神奈川県仃勤務）に対し 心から感謝の意を表します。

\section{[注 䣋]}

1）本研究は戸沼・佐藤（1977）に掉いて 1970 年までのデー 夕定用い分析したものに，1975 年のデータを加え，連担 市街地を一つの市街地とみなして分析しなおしたもので ある。

2) 市街地の規定方法については高山 (1949), 大友 (1959), 同 (1963), 同 (1971), 太田 (1964) などに詳述されてい る。

3）たとえば飯沼（1942）は「共武政表」による人口統計と 「地租改正紀要」所揭の市街地面積により, 明治初期の都 市機能別の 市街地人口密度を算定している。そ㧈による 之 1 市街地当りの平均は, 百坪当り城下町 6.98 人 $(2.09$ 万人 $\left./ \mathrm{km}^{2}\right)$, 港町 9.96 人 $\left(3.02\right.$ 万人 $\left./ \mathrm{km}^{2}\right)$, 宿場及市町 9.97 人 $\left(3.02\right.$ 万人 $\left./ \mathrm{km}^{2}\right)$, 門前町 9.50 人 $(2.88$ 万人 $\left.\mathrm{km}^{2}\right)$, その他 6.10 人 $\left(1.85\right.$ 厅人 $\left./ \mathrm{km}^{2}\right)$ となっている。 また正井 (1971) は種々の分析により, 市街地人口密度を 明治期 2 万人 $/ \mathrm{km}^{2}$ ，大正期 1.5 万人 $/ \mathrm{km}^{2}$, 昭和期 1 万人 $/ \mathrm{km}^{2}$ 之設定している。

また内藤（1966）は江户の人口密度を『武家地 16816 人/ $/ \mathrm{km}^{2}$, 社寺地 5682 人 $/ \mathrm{km}^{2}$, 町人地 67317 人 $/ \mathrm{km}^{2}$ 』 (p. 86) と推計している。

4）川上 (1975) \&郊外地に尔ける密度構造の变化を指摘して いる。 


\section{参考 献}

総理府統計局 $1962,66,72,77$ 「昭和 $35,40,45,50$ 年国勢調査 報告，別巻敄が国の人口集中地区」

太田，実 1964 「都市の地域構造に関する計画的研究」建築 雑誌, 943 号

飯沼二郎 1942 「明治初年における 農村耕地状態の地域的分 布に就て一幕末状態類推の一資料一」経済史研究，第 30 巻 5 号, $42 \sim 57$ 頁

大友 篤 1959「統計表章地域単位としての人口密集地区に ついて」統計局研究巢報，第 10 号，1１5 頁

大友 篤 1963 「昭和 35 年国樊調查人口集中地区について」 統計局研究巣報，第 12 号，1 34

大友 篤 1971 「Urban Population 表章のための人口集中 地区設定基淮改訂の提案」統計局研究彙報，第 21 号，17 $\sim 26$ 頁

大友 篤 1976 「人口集中地区人口の遡及推計 1888 年 1955 年」統計局研究彙報，第 30 号，29 48 頁

川上秀光 1975 「都市環境と都市計画」人間と都市環境一(2) 大都市周辺部, 鹿島出版会

高山英華 1949 「都方計画より兌た密度に関する研究」

高田和曉 1975 「わが国大都市圏における人口・産業の動向

\author{
とそのパターン」地理学評論, 第 48 巻 5 号, 331〜350 頁 \\ 内藤 昌 1966 「江戸と江戸城」鹿島出版 \\ 西藤冲他 1979 「ケーススタディ国土計画一全国計画例」土 \\ 木工学大采 22 , 彰国社 \\ 正井泰夫, 松本園子 1971 「関東地方における明治 - 大正 · \\ 昭和期の市街地分布」地理学評論, 第 44 巻 1 号, 1 13 \\ 頁 \\ 森川 洋 1962 「明治初年の都市分布」人文地理, 第 14 巻 5 \\ 号, 45 63 頁 \\ 吉阪隆正，青野 紘 1968 「都市の市街化過程の類型と構造 \\ の研究」日本都市計画学会学術講演会諭文集, 第 3 号, \\ $85 \sim 92$ 頁 \\ 吉阪隆正, 戸沼幸市 1965 「都市の大きさについての研究 1〜 \\ 4」日本建築学会論文報告集，第 116 119 号 \\ 吉阪隆正，戸沼幸市 1969 「都市論」建築学大系 2, 彰国社 \\ 戸沼幸市，佐藤 滋 1977 「密度を尺度とした市街地の変容 \\ 過程に関する研究」昭和 52 年度日本建築学会関東支部研 \\ 究報告集, p. $337 \sim$ p. 348 \\ 同 昭和 52 年度日本建築学会学術講演梗概集, p. 1319 \\ p. 1324
}

\title{
S Y NOPSIS
}

UDC : $711.552: 711.644$

\section{A STUDY ABOUT TRANSFORMATION PROCESSES OF DENSELY INHABITED DISTRICTS}

\author{
Part I; The change of urban size and density
}

by SHIGERU SATO and KOICHI TONUMA, Members of A.I.J.

In this study the transformation processes of urban sizes and densities from 1960 to 1975 are analized. For the 3 purpose of this, we used census data about Densely Inhabited District (DID) "which is defided as an area within a $\mathrm{shi}, \mathrm{ku}$, machi or mura that is composed of a group of contiguous enumeration districts each of which has a population i] density of about 4000 inhabitants or more per square kilometer, and whose total population exceeds 5000 as of 1 . October 1960, 1965, 1970, 1975." And DID's were originally established in each shi, ku, machi, mura. However, the contiguous DID's spreading over the boundary of shi, ku, machi, mura are counted as one contiguous DID in this study. So, Tokyo contiguous DID which is equal to Tokyo Metropolitan Area has 19.3 millions inhabitants and 1909 square kilometers. And we defined Urban Size Index which is product of DID's population and area.

The findings are as following.

i) There are remarkable differences among three periods from 1960 to 1975. In the first period (1960-1965), rapid urban growth had occured only in the three metropolitan areas, Tokyo, Osaka, Nagoya. So we could name this period "the preparation period for next rapid expansion".

And many DID's had rapid growth tendencies on size and declining tendencies on density all over the country in the second period. So we named this period "the rapid expanding period".

The third period (1970-1975) is "the settling period", when the number of of the DID's that grew with resing tendencies on density had been increasing.

We could characterize the three periods as This.

ii) We found regional characteristics of urban growth in relation with these three periods. In general, urban growth power had been only in the three metropolitan areas in the first period, and it had expanded to the Middle Japan (Kanto, Chubu, Kinki Region) in the second periods. And we can point out that the power extended to the South Japan (Chugoku, Sikoku, Kyushyu Region) which includs the Coastal Area of the Inland Sea of Seto which forms a part of "Tokaido Belt Chitai (the Megalopolis of the Coastal Zone of the Pacific Ocean)" in the third period (1970-1975).

But the urban growth power had never extended to the whole area in the North Japan (Hokkaido, Tohoku and Hokuriku Region) in even the third period.

iii) The changing process of DID's size and density is affected by its size. Some of DID's whose Urban Size Index is 100000 (person $\cdot \mathrm{km}^{2}$ ) or less are growing rapidly and some of them have declining tendencies on their sizes. But the DID's whose Urban Size Index is 1000000 (person $\cdot \mathrm{km}^{2}$ ) or more have necessarily gradual growing tendencies. 